\title{
'People take you more seriously': the perceived value of a PhD degree and the
}

\section{skills mismatch in the labour market}

\author{
Julia Heuritsch, Cathelijn J. F. Waaijer and Inge C. M. van der Weijden
}

Centre for Science and Technology Studies, Faculty of Social and Behavioural Sciences, Leiden University, Leiden, the Netherlands

Julia Heuritsch - Twitter: @intrinsic_space

Cathelijn J. F. Waaijer - ORCID: 0000-0002-1192-4909, Twitter: @ CJFWaaijer

Inge C. M. van der Weijden - ORCID: 0000-0001-5255-3430, Twitter: @WeijdenInge

\section{Abstract}

Increasing numbers of doctorate graduates work outside academia. This raises the question to what extent doctoral education offers the skills that are required for non-academic employability. In a survey of 2,193 recently graduated $\mathrm{PhDs}$ from Dutch universities, we studied what recent $\mathrm{PhD}$ graduates perceive as the main value of a $\mathrm{PhD}$ degree. $\mathrm{In}$ addition, they indicated to which extent they developed certain skills during the $\mathrm{PhD}$ and the extent to which they need them in their current job. The main values that doctorate holders attach to their doctoral education and degree are preparation for career goals, development of research skills, enjoyment, and social status. Most of the values mentioned are geared towards academic careers. Furthermore, we show that scientific skills are developed sufficiently during doctoral education, but management and social skills are not. This mismatch is larger for $\mathrm{PhD}$ holders working outside the academia than within academia.

\section{Keywords}

$\mathrm{PhD}$ graduates, doctoral education, employability, career development, skill acquisition, skills mismatch 


\section{Introduction}

$\mathrm{A} \mathrm{PhD} \mathrm{degree} \mathrm{has} \mathrm{been} \mathrm{regarded} \mathrm{as} \mathrm{the} \mathrm{gateway} \mathrm{to} \mathrm{an} \mathrm{academic} \mathrm{career,} \mathrm{which} \mathrm{is} \mathrm{often} \mathrm{seen} \mathrm{as}$ the 'default' career for PhD graduates (Stemwedel 2013). In the same vein, careers outside academia are seen as 'alternative careers'. Still, in many countries, more $\mathrm{PhD}$ graduates will work outside academia than within it, as shown by the Careers of Doctorate Holders Survey conducted by the United States, Taiwan and several European countries (Auriol et al. 2013). Therefore, several academics have argued that 'alternative careers' should not be called such, and that academic careers should be considered the alternative career option (Anonymous author 2014; Stemwedel 2013).

In line with this development, the purpose of doctoral education has shifted. As described by Kehm $(2006,67)$, 'doctoral education and training is no longer exclusively regarded as the disinterested pursuit of knowledge, but [...] the generation of new knowledge has become both an important strategic resource and a factor in a country's economy' (Kehm 2006). This raises the question whether doctoral education suitably prepares individuals for post- $\mathrm{PhD}$ employment - does doctoral education provide added value on the labour market and are skills developed in doctoral education aligned with the skills needed in post- $\mathrm{PhD}$ employment?

This question of employability can be examined from different points of view, such as from a higher education policy point of view (e.g., Kehm 2006; Rip 2004) or from an employer point of view (e.g., Stassen et al. 2016). However, in this study we examine this question from the point of view of doctoral graduates themselves. They are arguably the party for whom it is most important that doctoral education has value.

Our research questions are:

1. What do recent $\mathrm{PhDs}$ perceive to be the main value(s) of their doctoral education and PhD degree? 
2. Which skills do recent PhDs feel they have acquired during doctoral education and which ones do they feel they need in their current jobs? In other words: which skill (mis)matches do recent $\mathrm{PhDs}$ perceive?

3. Do perceived skill (mis)matches differ by current sector of employment and if so, which characteristics influence the mismatch?

Our study is set among recent $\mathrm{PhD}$ graduates from five Dutch universities. The Dutch case is especially interesting to study, as the Netherlands has the greatest share of $\mathrm{PhD}$ graduates working outside the higher education sector of all countries participating in the CDH survey (Auriol et al. 2013). A large majority of $\mathrm{PhD}$ graduates (eighty per cent) work as researchers, but only a quarter of them in the higher education sector (Maas et al. 2014). The remaining twenty per cent do not work as researchers, most of them in the non-profit sector. Therefore, for a large majority of $\mathrm{PhD}$ graduates in the Netherlands the value of the $\mathrm{PhD}$ degree will be another than to serve as a gateway to an academic career. This makes it especially important to study the alignment of doctoral education outcomes with the post-PhD labour market.

\section{Theoretical background}

In our study, we examine the value of doctoral education from the perspective of (perceived) employability. First, we will give a background to the concept of employability. Second, we describe doctoral education in the Netherlands, as the value of doctoral education naturally depends on the context of this education. In the same section, we will also give an overview of post- $\mathrm{PhD}$ employment in the Netherlands. Post-PhD employment trends are important to bear in mind when interpreting our results, because we hypothesise that employability resulting from doctoral education differs by sector of employment. Third, we will discuss earlier studies on the value of the PhD. Fourth, we will discuss earlier work on skills mismatches after doctoral education. 


\section{Employability}

The concept of employability has gained considerable ground in labour market policy, as already noted in 2005 by McQuaid and Lindsay (McQuaid and Lindsay 2005). Several definitions of employability exist, but we use the definition coined by Yorke (2006): 'a set of achievements - skills, understandings and personal attributes - that makes graduates more likely to gain employment and be successful in their chosen occupations, which benefits themselves, the workforce, the community and the economy'. We use this because our study focuses on the relationship between doctoral education and current employment of $\mathrm{PhD}$ graduates, so it is relevant to concentrate on the short-term aspect of employability. However, we must note that other definitions of employability also exist, which are more geared towards the long-term. For example, Fugate et al. (2004) define employability as the ability to develop skills needed to adapt to a changing work environment, which can of course last an entire working life.

\section{Doctoral education and post-PhD employment in the Netherlands}

Doctoral education in the Netherlands has historically been an endeavour started, managed and finished by two individuals: the PhD candidate and the doctoral supervisor. However, since the 1980s a trend towards collectivization of doctoral education has started, and graduate and research schools founded. At the same time, the master-apprentice relationship is still present in $\mathrm{PhD}$ trajectories (Sonneveld 1997). In principle, $\mathrm{PhD}$ are appointed as employees, being paid from university funds or governmental research funding (Bartelse et al. 2007). Still, there is a large group of $\mathrm{PhD}$ candidates who do not have employee status. This group roughly consists of scholarship $\mathrm{PhD}$ candidates (often non-Dutch $\mathrm{PhD}$ candidates with a scholarship from a nonDutch government of funding organization) and external $\mathrm{PhD}$ candidates who work on a dissertation next to another job or after retirement (Waaijer et al. 2016). This diversity in funding and status leads to differing $\mathrm{PhD}$ experiences (Waaijer et al. 2016). Another trend has 
been the transition from monographs to article-based dissertations (Waaijer et al. 2016). On average, $\mathrm{PhD}$ candidates have 4.25 papers accepted in international, peer-reviewed journals around the time of PhD degree conferral (Sonneveld et al. 2010). Finally, the demographics of $\mathrm{PhD}$ candidates have changed, the share of women increasing from less than a quarter in 1990 to almost half in 2010 (de Goede et al. 2014). In addition, demographics have become slightly more international. In 2003, 69 per cent of employed PhD candidates had the Dutch nationality, whereas in 2016, it was 52 (de Jonge, 2018). On average, $\mathrm{PhD}$ candidates in the Netherlands are 29.5 years old when they obtain the $\mathrm{PhD}$ degree (de Jonge, 2018). This average age is most likely the result of a large variation in ages, employed $\mathrm{PhD}$ candidates typically starting doctoral education straight after the completion of their master's degree and being younger at completion, whereas external $\mathrm{PhD}$ candidates working on a dissertation next to other work (or after retirement) will be older.

\section{Value of doctoral education and PhD degree}

A large share of studies into the value of the PhD degree look at the (added) value compared to university graduates in terms of labour market outcomes and earnings. In most countries, unemployment is lower among $\mathrm{PhD}$ than university graduates (Auriol et al. 2013). In both the Netherlands and Germany, $\mathrm{PhD}$ graduates reach higher positions more often than university graduates and earn slightly more, although this finding is dependent on discipline (Enders 2002; Traag and Dirven 2008; van der Steeg et al. 2014). On the other hand, a PhD degree does not lead to a higher income in Denmark (Skovgaard Pedersen 2016).

Naturally, the value of doctoral education and $\mathrm{PhD}$ degree are important to $\mathrm{PhD}$ graduates themselves. Studies on this topic are thinly dispersed, both in terms of country and focus. Below we give an overview of the main findings of these sparse studies.

In Australia, $\mathrm{PhD}$ graduates judged the usefulness of the $\mathrm{PhD}$ degree for the current job and career very positively (Platow 2012). The study also measured to which extent PhD graduates 
feel they have acquired several attributes. However, in the article only the relation between this (compound) perception and the usefulness of the $\mathrm{PhD}$ for the current job and career is reported on, so it is not possible to obtain information on which attributes $\mathrm{PhD}$ graduates think they have acquired, and which not. In contrast, studies conducted in the United Kingdom and Norway, respectively, did show results on specific attributes. The UK study that added value of doctoral include improvement of social and intellectual abilities, confidence, development of problemsolving skills, and the self-belief one can learn and apply new techniques (Diamond et al. 2014). In the Norwegian study, the authors asked which elements should have been emphasised more in doctoral education according to $\mathrm{PhD}$ graduates (Kyvik and Olsen 2012). Mentioned most often were insight into project planning, research management and career planning. Furthermore, the authors asked to which extent $\mathrm{PhD}$ graduates use the knowledge obtained in their doctoral education in their current job. The $\mathrm{PhD}$ graduates indicate they use this knowledge, but graduates not involved in research use this knowledge less often than $\mathrm{PhD}$ graduates working at universities, colleges, or research institutes. Finally, an interesting question is which value employers attach to doctoral education and a $\mathrm{PhD}$ degree. As most studies on this issue focus on the skills that $\mathrm{PhD}$ graduates can offer employers, and the perceived mismatch between the skills acquired in doctoral education and those required on the labour market, we will discuss the topic in the next, separate, section on skills mismatches.

\section{Skills mismatches}

Using a survey among $\mathrm{PhD}$ graduates, $\mathrm{PhD}$ candidates and employers, Durette and colleagues (2016) distinguished six types of core competencies acquired in doctoral education: knowledge and technical skills, transferable competencies that can be formalised (such as communication, innovation management, project management and language skills), transferable competencies that cannot be formalised (such as cognitive abilities, the abilities to deal with complex 
problems, and the ability to collaborate), dispositions (such as rigor, creativity and autonomy), behaviours (such as perseverance) and meta competencies (such as the capacity to adapt).

At the same time, De Grande and colleagues (2014) identify a gap between the skills that $\mathrm{PhD}$ graduates in Flanders think are important in a career in industry and the skills that industrial employers require. Even more importantly, in an earlier study the same group of researchers identify a mismatch between the extent to which $\mathrm{PhD}$ graduates think they have acquired several skills and the extent to which they think the same skills are required in their current job (te Kaat and Vandevelde 2010). The mismatch is especially large when it comes to team skills and management skills, regardless of whether the $\mathrm{PhD}$ graduates work in industry, the service sector or academia. The mismatch is echoed by Kyvik and Olsen (2012) who asked $\mathrm{PhD}$ graduates which elements should have been emphasised more in doctoral training and found that $\mathrm{PhD}$ graduates felt that collaboration (both in the research group, with different disciplines and with industry), commercialization, and career planning should have been emphasised more.

In Finland, a study found that the value of $\mathrm{PhD}$ graduates to employers only lay in $\mathrm{R} \& \mathrm{D}$ work, and that doctoral education was only of limited value (Haapakorpi 2015). In contrast, in the United Kingdom, employers indicate that they highly value $\mathrm{PhD}$ graduates' research and analytical skills, critical thinking capacity, the ability to bring fresh perspectives, and tenacity (Diamond et al. 2014). Skills that could be developed more include commercialization and leadership skills. A recent published study from the US showed that $\mathrm{PhD}$ graduates who make the transition into non-academic careers lack relevant skills; they do not possess leadership and teamwork experiences required for industry or start-up teams that integrate multiple functions, such as, research, management, manufacturing and sales (Hayter and Parker 2019).

In this study, we will study the relationship between doctoral education and employability. Which (added) value of doctoral education and the $\mathrm{PhD}$ degree do $\mathrm{PhD}$ graduates identify in 
relation to their career? Do they perceive a mismatch between the skills developed in doctoral education and the skills currently needed and does this differ by sector?

\section{Data and methods}

\section{Survey methodology}

Names of all the PhDs who graduated between April 2008 - March 2009 were obtained from 4 universities (two general universities, one university of technology and one agricultural university) in the Netherlands. A fifth Dutch (general) university provided us with names of all individuals who obtained their PhD between January 2008 and May 2012. This amounted to a total of 2,410 PhDs, of which 2,193 could be contacted. This sample represents roughly $40 \%$ of all $\mathrm{PhD}$ graduated in the Netherlands in that specific time frame (Onderwijs in Cijfers 2019). Data were obtained from 1,133 respondents (response rate just over 50\%). A comparison of the characteristics of the respondents and the $2,410 \mathrm{PhDs}$ in the complete set shows that the respondents are a good representation of year of $\mathrm{PhD}$, city of $\mathrm{PhD}$, gender, and age (Waaijer et al., 2015).

\section{Variables}

Our questionnaire contains mainly multiple-choice questions but also a small number of open questions. Questions cover employment status, job choice, perception of career prospects, use of skills developed during the $\mathrm{PhD}$, and mentoring during the career. The survey was pretested among $\mathrm{PhD}$ holders not included in the survey sample. More detailed information on the sample, survey methodology and questionnaire can be found in Waaijer et al. (2015). In this paper, we will mainly focus on the questions concerning skill development.

The main value of doctoral education and the PhD degree according to the respondents was measured through an open question. Two coders independently coded the answers in a 
grounded approach. The coders discussed their themes and codes, and together came to an agreement on the final themes and codes.

The extent to which skills were developed during doctoral education and required in the current job were measured on a three-point scale (1= 'no', 2= 'yes, somewhat', 3= 'yes, very much'). We measured the development and requirement of thirteen skills, which were chosen based on the skills Flemish doctorate holders indicate to have developed most (te Kaat and Vandevelde 2010). These were scientific knowledge, analytic thinking, social skills, teamwork, independence, initiative, stress management, self-confidence, learning ability, presentation skills, writing skills, language acquisition skills, and project management skills. Although these are ordinal variables, they were treated as continuous ones in order to visually show skills mismatches in a single plot (in Fig. 1).

The relatedness of the content of the current job to the PhD topic was measured on a four-point scale, with "1" being "not related at all" and "4" being "very closely related". Three sectors of employment were distinguished: academia, non-academic $\mathrm{R} \& \mathrm{D}$, and non-R\&D. The grouping of the respondents into these categories was based on two variables: involvement in R\&D and type of employer. If $\mathrm{PhD}$ graduates were involved in basic research, applied research, or experimental development (OECD 2002) in their main job, and employed at a university, university of applied sciences or college, academic hospital, or research institute, they were classified as working in academia. If they were involved in R\&D and working at another type of institution (e.g., at a private business, government institution, or non-academic hospital), they were classified as working in non-academic $\mathrm{R} \& \mathrm{D}$. PhD graduates not involved in any of the three types of $R \& D$ in their main job were classified as working in non-R\&D.

Fields of $P h D$ were one of the following: medical and health sciences, natural sciences (including agricultural sciences), social sciences, humanities, and engineering and technology. 
Finally, we also measured the respondents' gender and age at filling in the survey, as these factors may influence the perception of skills (Ehrlinger and Dunning 2003).

\section{Statistical analysis}

To reduce this number to underlying constructs, we performed a factor analysis using Principal Component Analysis and polychoric correlation techniques, with FACTOR (Lorenzo-Seva and Ferrando 2006). This resulted in the reduction of the thirteen skills to three factors: scientific skills, independence, and management \& social skills (Table S-1). Reliability of the three scales was determined by computing the Cronbach's $\alpha$ score. Factor analysis showed a slightly different delineation of factors for the extent to which a skill was developed and the extent to which it was required. Language acquisition skills and project management skills had the highest factor loadings on different factors for skills development and skills requirement. For simplicity we chose to group language acquisition skills with 'scientific skills' and project management skills with 'management and social skills'. The factor loadings for the factor to which we chose to map them, was only slightly lower than the highest factor loading (factor loading shown in table).

The scores on the three resultant scales were normally distributed and thus suitable for parametric statistical tests. Differences in skills mismatches between sectors were tested for statistical significance using ANOVA with a post-hoc Bonferroni test. To evaluate the association of several independent variables on skills mismatches and job satisfaction, linear regression was used. Figures were made in R using the ggplot2 and geom_mosaic packages.

\section{Results}

\section{Value of doctoral education and the PhD degree}

The survey included an open question what the main value of the $\mathrm{PhD}$ degree has been for PhDs. We coded their answers into six broad categories, which were further subdivided into 34 
subcategories (Table 1). As can be seen from the table, the most prominent values were Research skills in general, Analytical thinking, Independence, that the $\mathrm{PhD}$ is Needed for a career in academia and Social status. Many PhDs indicated they developed research skills during their $\mathrm{PhD}$ project, including analytical and critical thinking. Working on a $\mathrm{PhD}$ degree does not usually include much work in teams, hence only few PhDs state that they gained skills in working with others, but instead learned how to work independently. This includes project management skills:

I learned how to take charge of your own project. Don't depend too much on others, determine for yourself which direction is best, influence people to go with you in that direction. (male, $\mathrm{PhD}$ in medical and health sciences in 2009, non-academic R\&D).

$\mathrm{PhD}$ graduates may have started their $\mathrm{PhD}$ project out of curiosity for science and academia and a wish for an intellectual challenge. Many reported that they like the (focused) research work and the academic experience:

Being able to dive into a subject for four years and learning to work in an academic environment. (female, $\mathrm{PhD}$ in medical and health sciences in 2008, non-R\&D).

Another main value was the fact that the $\mathrm{PhD}$ degree is needed for the further career (especially in academia, but also in general). In addition, $57 \%$ of the $\mathrm{PhD}$ graduates who said that the degree was needed for their future career in academia mentioned only that value, which further confirms this as an important value of the $\mathrm{PhD}$ degree.

My PhD has been fundamental for my wish to develop a career in academia. I have been trained to think and write critically and analytically, and to develop a research project, skills that will feed into my future work. (female, $\mathrm{PhD}$ in humanities in 2009, non-R\&D). 
In addition, the $\mathrm{PhD}$ degree offers social status. Note that we defined social status as the status that comes automatically with the title. Other respondents indicated a main value of doctoral education had been the higher qualification that they obtained (e.g., having become an expert in a field), but these answers were coded as a separate category. The social status connected to the $\mathrm{PhD}$ degree leads to recognition being more self-evident:

The title sometimes gives you an advantage when you are looking for a job and people take you more seriously. (male, $\mathrm{PhD}$ in natural sciences in 2008, non-R\&D).

$\mathrm{PhD}$ graduates also mentioned that doctoral education taught them transferable skills, such as writing and management, and that the $\mathrm{PhD}$ degree has led to benefit their personal development:

I can respect others more than before, because [the] process of being a PhD is more important that holding a PhD degree. (female, PhD in natural sciences, 2008, sector unknown).

Obtaining a $\mathrm{PhD}$ degree also gave personal satisfaction in terms of a sense of accomplishment and teaches perseverance:

The sense of accomplishment: knowing that whatever comes next, you've already done the hardest thing you'll ever do (and have survived it). (male, $\mathrm{PhD}$ in social sciences in 2010, academia).

Other values of doctoral education and the PhD degree include opportunities for travelling, working internationally, contributing to society, flexibility in life, experience with grants and publications and being able to deal with complicated problems also in practice:

[...] If I look at my current job, having done my PhD is really a plus. You know how the scientific world works and that helps a lot in communicating with the researchers that apply for funding with us. Additionally, the network I [built] up during my PhD is really helpful now as well. (female, $\mathrm{PhD}$ in natural sciences in 2009, non-R\&D). 
However, some $\mathrm{PhD}$ graduates stated that the $\mathrm{PhD}$ degree has no value for them or even stated that it could put them at a disadvantage with respect to their future career due to overqualification. It must be said their number was limited at only 24 out of 859 responses to the question. One reason they mentioned was their disillusionment with science as their experience was different than they expected at the beginning of their PhD project when they started out of curiosity:

Little. It is a great title to predestine you for an unguided, self-made patchwork academic career, filled with uncertainty. (male, $\mathrm{PhD}$ in medical and health sciences in 2008, academia).

The fact that people outside academia think it's important. In academia it's only important to get in. Everybody knows its value is hugely decreased i.e. counts for very little - as everybody in academia seems to have a PhD while many know not all should have 'passed the test'. The title is thus greatly devaluated. I personally don't care about this. It's just something I think academia needs to reconsider. (female, $\mathrm{PhD}$ in humanities in 2008, academia).

I did my PhD because at that time, I believed it would be a good 'investment' and that having the PhD degree would open up more interesting job opportunities. To be honest, at the moment I'm not sure about that anymore, but I do not regret doing my PhD research. (female, $\mathrm{PhD}$ in natural sciences in 2009, non-R\&D).

\section{Skill mismatches}

Our second research question was which skills recent $\mathrm{PhDs}$ feel they have acquired during doctoral education, which ones they feel they need in their current jobs, and which mismatches there are between the two. To answer this question, the extent to which the thirteen skills were acquired on average during doctoral education was plotted against the extent to which those skills are required on average in the $\mathrm{PhD}$ graduates' current jobs (Fig. 1). 


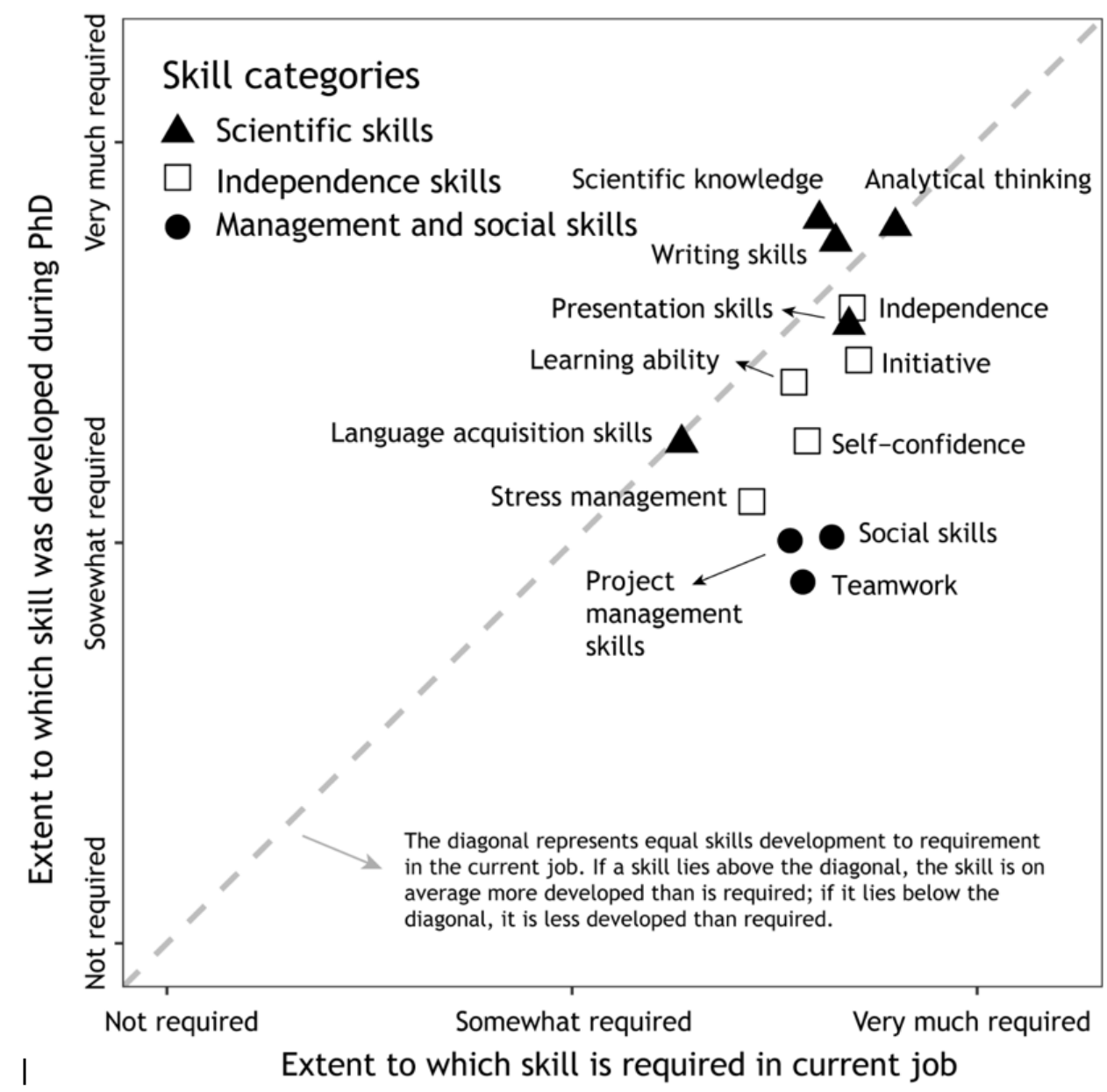

\section{Figure 1. Skills mismatches}

The extent to which the thirteen skills were developed on average during the $\mathrm{PhD}$ plotted against the extent to which those skills are required on average in the current job. The skill categories correspond to the three skills categories distinguished by factor analysis.

Developed to the largest extent were scientific knowledge, analytic thinking, and writing skills. Least developed were teamwork, social skills, and project management skills.

The further skills are located away from the diagonal, the larger the mismatch is. Lying above the diagonal translates to a positive skill mismatch, which means that skills were acquired to a larger extent than they are required in the current job. Under the diagonal lie the skills that were developed to a smaller extent than they are required in the current job. There are only small skills mismatches in scientific knowledge, analytic thinking, independence, learning ability, presentation skills, writing skills, and language acquisition skills. The largest skills mismatches 
are found in teamwork, social skills, and project management skills. These were all underdeveloped relative to the extent to which they are needed in the current job.

\section{Skills mismatches by sector of employment}

Next, we investigated whether skills mismatches differ by sector of employment, as one may expect the different sectors where PhD graduates work to have different skills requirements. For these factors the development was plotted against the requirement, by sector of employment (Fig. 2).

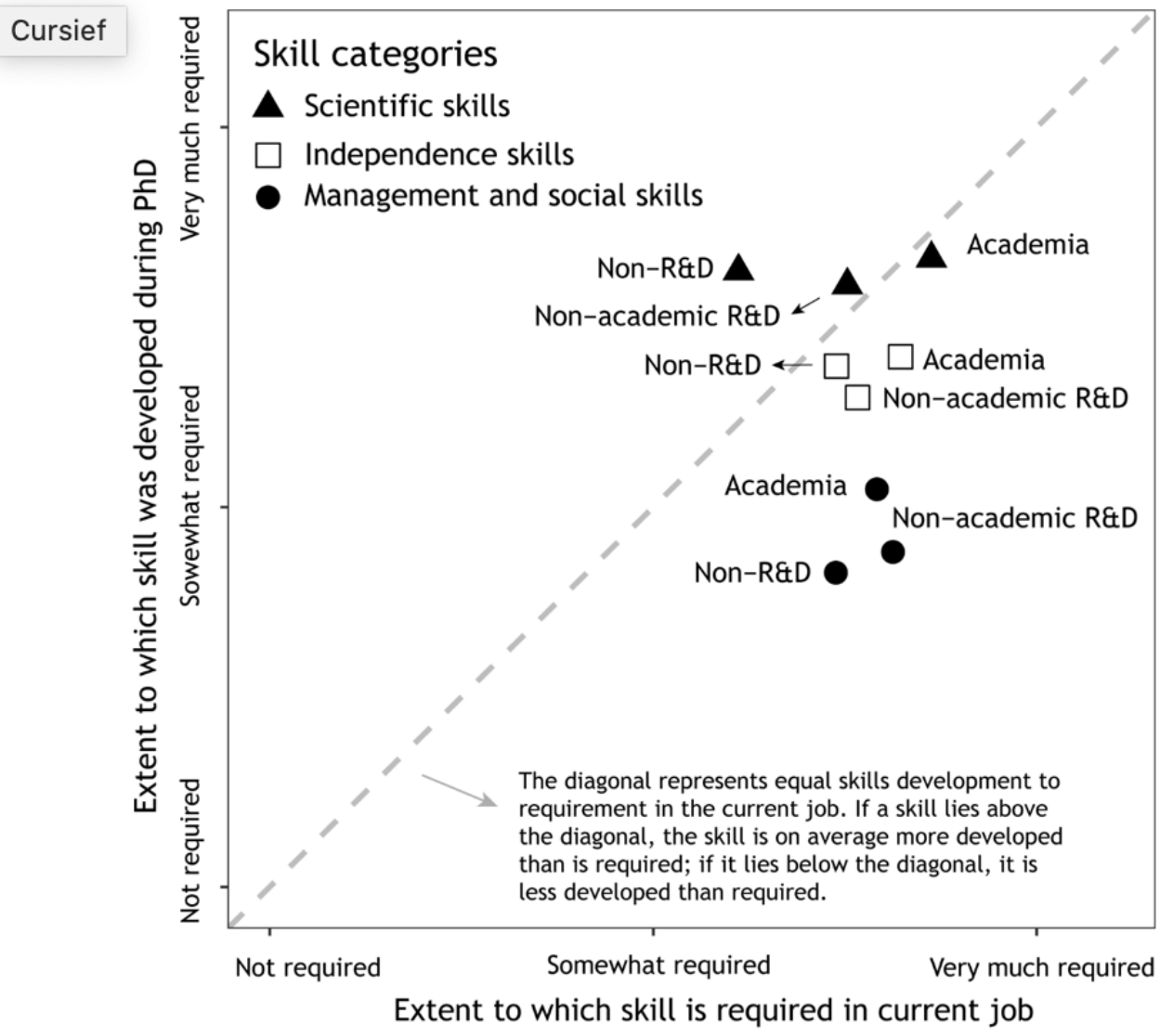

Figure 2. Skills mismatches by sector of employment (three skill categories)

The extent to which the three skill categories (distinguished by factor analysis) were developed on average during doctoral education plotted against the extent to which those skills are required on average in the current job, by sector of employment.

Scientific skills are situated close to the diagonal, which means that they were sufficiently developed during doctoral education. In contrast, $\mathrm{PhD}$ graduates reported management $\&$ social 
skills to be underdeveloped compared to the requirements of their current jobs. Mismatches in independence skills fall in-between the mismatches in scientific and management \& social skills.

A comparison between the sectors of employment shows that the mismatch in management \& social skills is significantly larger in non-academic R\&D than in academia $(p<0.001)$. Independence skills were significantly less underdeveloped in non-R\&D compared to both nonacademic $\operatorname{R} \& D(p=0.041)$ and academia $(p=0.003)$. Finally, scientific skills were slightly underdeveloped for $\mathrm{PhD}$ graduates working in academia, but slightly overdeveloped for $\mathrm{PhD}$ graduates working in non-academic $\mathrm{R} \& \mathrm{D}(p<0.001)$. The overdevelopment was largest for $\mathrm{PhD}$ graduates working in non-R\&D (differences to both academia and non-academic $\mathrm{R} \& \mathrm{D}$ statistically significant at $p<0.001)$.

Next, we investigated which sectoral characteristics could underlie these different skills mismatch patterns by sector. An earlier study based on this survey showed that the educational requirement of jobs tends to vary by sector, with a larger share $\mathrm{PhD}$ graduates working at master's level in non-academic R\&D and non-R\&D than in academia (Waaijer et al. 2017). Furthermore, we expected the job content of $\mathrm{PhDs}$ in academia to be more related to the $\mathrm{PhD}$ topic than of $\mathrm{PhD}$ graduates working outside academia. To assess the latter expectation, we plotted the relatedness of the job content to the PhD topic by sector of employment (Fig. 3). This showed that our expectation held true. 

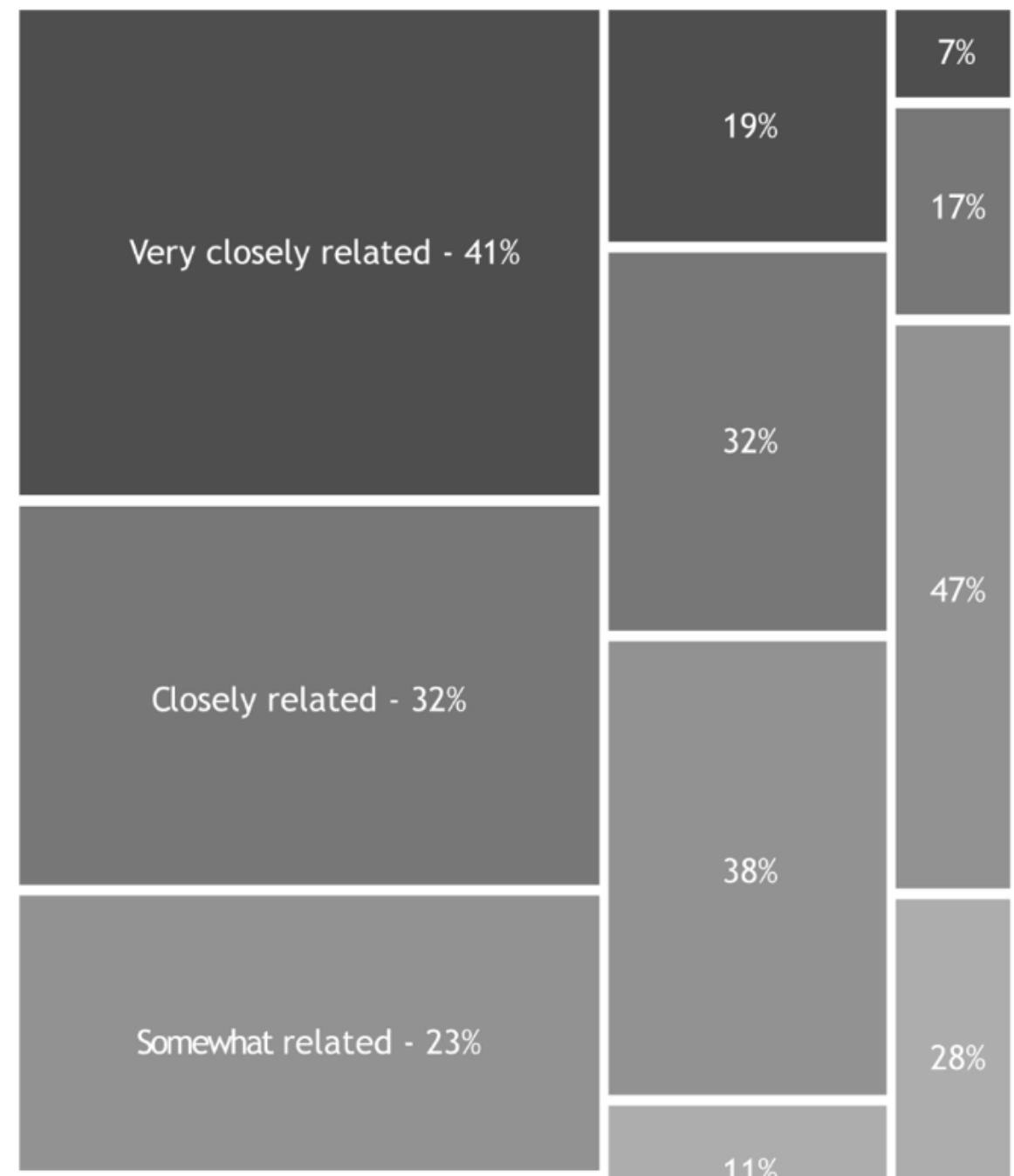

Not related at all $-4 \%$
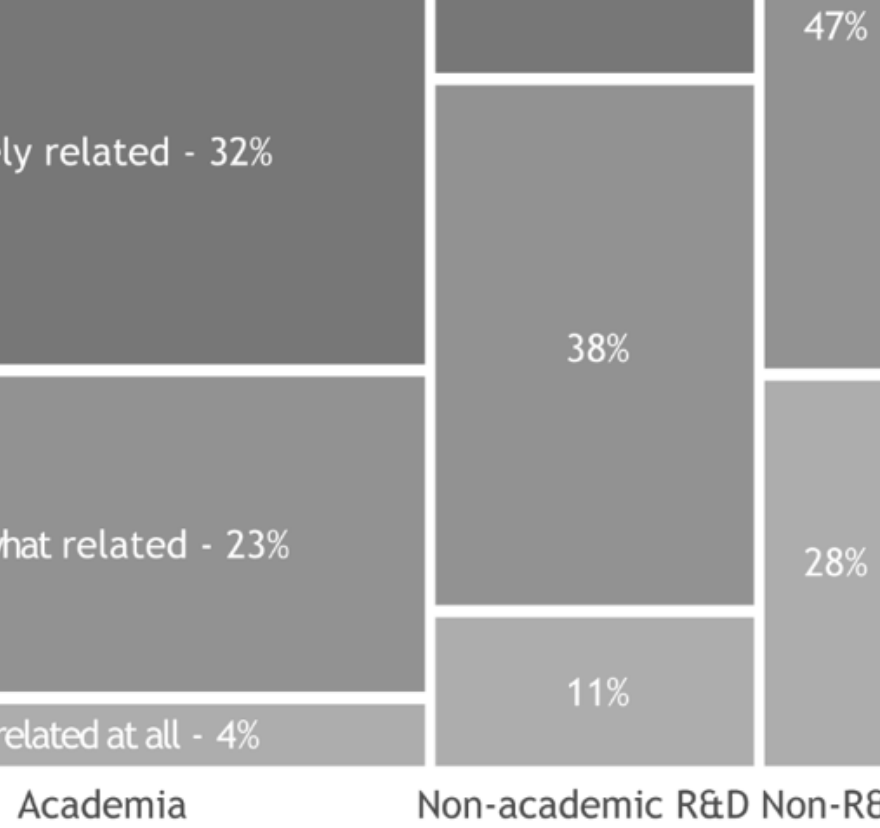

I $\quad(n=560)$

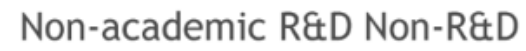

$$
(n=268) \quad(n=110)
$$

Figure 3. Relatedness of $\mathrm{PhD}$ topic to current job by sector of employment

Both sector characteristics could explain part of the differences in perceived skills mismatches. We next assessed factors are independently associated with skills mismatches. To this end, we built a linear regression model on scientific skills, independence, and management \& social skills mismatches with sector of employment, relatedness of the job to the $\mathrm{PhD}$ topic and educational level required for job as the main independent variables (Table 2). Furthermore, we added the independent variables gender and age at the time of the survey, as these may influence the results. The skills mismatch was computed by subtracting the requirement of a skills 
category from the development of a skills category for each $\mathrm{PhD}$. This means the more positive the number, the more a skills category is overdeveloped. The more negative the number is, the more underdeveloped it is.

The model for the scientific skills mismatch showed that scientific skills were more overdeveloped if a $\mathrm{PhD}$ graduate worked in non-R\&D. In addition to sector, the educational level required for the job and the relatedness of the current job to the $\mathrm{PhD}$ topic were independently associated with a mismatch in scientific skills. If the job was not at PhD level, scientific skills tended to be more overdeveloped. Conversely, the more related the job was to the $\mathrm{PhD}$ topic, the more negative the skills mismatch (which means the skill was more underdeveloped). A higher age at filling in the survey (and thus also at $\mathrm{PhD}$ conferral) was associated with a more negative skills mismatch. $\mathrm{PhD}$ graduates with a $\mathrm{PhD}$ degree in medicine had slightly more overdeveloped scientific skills than $\mathrm{PhD}$ graduates from engineering and technology. Gender was not statistically significantly associated with a mismatch in scientific skills.

The model for the independence skills mismatch showed no statistically significant effect of sector of employment, nor for the field of $\mathrm{PhD}$ degree or gender. Independence skills were overdeveloped if a $\mathrm{PhD}$ was working on bachelor or lower level. Conversely, the closer related the $\mathrm{PhD}$ topic was to the job content, the more underdeveloped independence skills were. Again, a higher age at filling in the survey was associated with a more negative skills mismatch.

The model for the management \& social skills mismatch showed that $\mathrm{PhD}$ graduates working in non-academic $\mathrm{R} \& \mathrm{D}$ had a larger skills mismatch than $\mathrm{PhD}$ graduates in academia; the management $\&$ social skills were more underdeveloped relative to the skills requirement. $\mathrm{PhD}$ graduates having a job at master's level also had more underdeveloped management $\&$ social skills than $\mathrm{PhD}$ graduates working at $\mathrm{PhD}$ level. Medical $\mathrm{PhD}$ graduates had overdeveloped management and social skills more than their colleagues from engineering and technology. 
Again, higher age was associated with more underdeveloped skills. Relatedness of neither the $\mathrm{PhD}$ topic nor gender had an independent association with the management \& social skills mismatch.

\section{Discussion and conclusions}

In this study, we assessed the value of doctoral education and the $\mathrm{PhD}$ degree to recent $\mathrm{PhD}$ graduates from Dutch universities. Furthermore, we investigated mismatches between developed skills during doctoral education and those needed in the current jobs of $\mathrm{PhD}$ graduates according to $\mathrm{PhDs}$ themselves.

We found that the main values $\mathrm{PhD}$ graduates attach to their degree are a fit with their career goals, development of skills, social status and the fact it enabled them to do something they liked. Here, we saw that the values attached to doctoral education and the $\mathrm{PhD}$ degree are mainly geared towards academia and scientific skills: whenever a fit with career goals was described, it tended to concern a career goal in academia and when skill development was mentioned, it most often concerned research skills, analytical thinking, independence, and scientific knowledge.

Our assessment of the skills that $\mathrm{PhD}$ graduates developed during doctoral education corroborated that $\mathrm{PhD}$ graduates think they have mainly developed scientific skills, but other skills, especially teamwork, social and project management skills much less so. At the same time, $\mathrm{PhD}$ graduates indicated these skills are very much needed in their current jobs. This is the case inside and outside of academia - but especially outside. Our results are in accordance with the findings of Te Kaat and Vandevelde (2010), Kyvik and Olsen (2012) and van der Weijden et al. (2017), whose studies also found mismatches in the skills developed during doctoral education versus those needed after the $\mathrm{PhD}$ degree, in Flanders, Norway and the 
Netherlands, respectively. They also found that the mismatch is larger when a $\mathrm{PhD}$ graduate works outside academia after the $\mathrm{PhD}$ degree.

We further investigated which factors related to the sector of employment affect the skills mismatch. We found that for $\mathrm{PhD}$ graduates working in academia the topic of their $\mathrm{PhD}$ degree is more often related to the content of the current job than for $\mathrm{PhD}$ graduates working in nonacademic $R \& D$ and (especially) in non-R\&D. The more related the $\mathrm{PhD}$ topic to the current job, the less overdeveloped scientific skills are, and the more underdeveloped independence skills are. In addition, the educational level required for the job differs by sector (Waaijer et al. 2017), with $\mathrm{PhD}$ graduates working outside academia more often working below PhD level. When not working at $\mathrm{PhD}$ level, scientific skills are more overdeveloped. Furthermore, when working at master's level, management \& social skills are more underdeveloped. In addition, age at filling in the survey played a role, higher age leading to smaller overdevelopment or larger underdevelopment. This may be due to the fact that these PhD graduates were also older at the time of starting the $\mathrm{PhD}$ - perhaps these $\mathrm{PhD}$ graduates had already developed these skills before doctoral education. A final interesting finding was that field of $\mathrm{PhD}$ was not strongly associated with a skills mismatch, the only difference found between medical $\mathrm{PhD}$ graduates and engineering and technology $\mathrm{PhD}$ graduates (with other factors such as sector, relatedness and educational level corrected for). This suggests our findings on the skills mismatch to be roughly similar in all scientific fields.

That brings us to a few caveats of the study. First of all, we only asked after the development of skills during doctoral education. It may well be the case that $\mathrm{PhD}$ graduates developed skills before that time. If this is the case, there would be no skills mismatch even if the skills are required in the job to a great extent. In addition, our results only pertain to the extent to which skills were developed and required according to $\mathrm{PhD}$ graduates themselves, and thus to a perceived skills mismatch. 
Our findings corroborate that skills such as teamwork and project management are vital in many jobs, both inside and outside academia (De Grande et al. 2014; Durette et al. 2016; te Kaat and Vandevelde 2010). However, such skills are developed during doctoral education in the Netherlands to a smaller extent than $\mathrm{PhD}$ graduates need for their later jobs. From our results, we can conclude that there is a mismatch in doctoral education in the Netherlands to what is needed in jobs after the PhD degree - leading to sub-optimal employability of PhDs.

Part of the explanation for this may lie in the outlook of $\mathrm{PhD}$ graduates themselves. As also indicated by their own answers, their perspective is often centred on a career in academia. In other countries, academia is also the preferred sector of employment, despite the fact that opportunities for academic employment have not kept pace with this increase of $\mathrm{PhD}$ graduates (Fitzenberger and Schulze 2014; Puljak and Sharif 2009; Sauermann and Roach 2012). To improve employability of $\mathrm{PhDs}, \mathrm{PhD}$ programs in the Netherlands should more explicitly show the multitude of careers possible for $\mathrm{PhD}$ graduates and enable a broader career development. Another recommendation is to integrate a broader social focus into $\mathrm{PhD}$ programs from the earliest stages for example by organizing visits to companies working in relevant fields or by offering joint research projects in which $\mathrm{PhD}$ students work together with business and industry (van der Weijden et al. 2017).

Our study shows that $\mathrm{PhD}$ graduates see a great (added) value to their $\mathrm{PhD}$ degree on the labour market. Still, a skills mismatch exists between doctoral education and the labour market. It is present but small for $\mathrm{PhD}$ graduates working in academia - but more prominent for $\mathrm{PhD}$ graduates working in the non-academic sector. As this is the sector in which most $\mathrm{PhD}$ graduates will eventually work, there is a need to better align doctoral education and the labour market. 
Table 1: Main value of doctoral education and PhD degree (859 responses to open question)

\begin{tabular}{lll} 
Category & N & (\% of filled in answers) \\
\hline Knowledge and skills development & $\mathbf{4 7 3}$ & $\mathbf{( 5 5 )}$ \\
Research skills in general & 150 & $(17)$ \\
Analytical thinking & 116 & $(14)$ \\
Independence & 111 & $(13)$ \\
Scientific knowledge & 78 & $(9)$ \\
Personal development in general & 57 & $(7)$ \\
Writing skills & 48 & $(6)$ \\
Critical thinking & 45 & $(5)$ \\
Project management skills & 41 & $(5)$ \\
Self-confidence & 36 & $(4)$ \\
Higher qualification (e.g. expert knowledge) & 28 & $(3)$ \\
Learning ability (opportunities to acquire knowledge, also includes & 20 & $(2)$ \\
languages) & 21 & $(2)$ \\
Skill development in general & 16 & $(2)$ \\
Skills in working with others (e.g., teamwork, social skills) & 16 & $(2)$ \\
Personal effectiveness in general (includes self-motivation) & 13 & $(2)$ \\
Presentation skills & 13 & $(2)$ \\
Perseverance & 10 & $(1)$ \\
Communication skills in general & 7 & $(1)$ \\
Reading skills & 5 & $(1)$ \\
Taking initiative & 5 & $(1)$ \\
Management skills in general & 4 & $(<1)$ \\
Stress management & $\mathbf{3 6 5}$ & $\mathbf{( 4 2 )}$ \\
Fit with career goals \& increase in job opportunities & 223 & $(26)$ \\
Needed for career in academia & 75 & $(9)$ \\
Needed for career goals in general & 49 & $(6)$ \\
Needed for career outside academia & 26 & $(3)$ \\
Networking & $\mathbf{2 1 4}$ & $\mathbf{( 2 5 )}$ \\
Fit with interest & 79 & $(9)$ \\
Like research/job in general & 71 & $(8)$ \\
Personal satisfaction & 54 & $(6)$ \\
Like other parts of the work & 27 & $(3)$ \\
Environment/colleagues & 19 & $(2)$ \\
Contribution to society & 15 & $(2)$ \\
PhD topic very interesting & $\mathbf{9 4}$ & $\mathbf{( 1 1 )}$ \\
Social status & $\mathbf{5 8}$ & $\mathbf{( 7 )}$ \\
Other & $\mathbf{1 8}$ & $\mathbf{( 2 )}$ \\
No value & & \\
\hline & & \\
\hline
\end{tabular}


Table 2: Effects of job and personal characteristics on skills mismatches (linear regression)

\begin{tabular}{|c|c|c|c|c|c|c|}
\hline & \multicolumn{2}{|c|}{ Scientific skills } & \multicolumn{2}{|c|}{ Independence skills } & \multicolumn{2}{|c|}{$\begin{array}{l}\text { Management } \\
\text { social skills }\end{array}$} \\
\hline & B (S. E.) & p-value & B (S. E.) & p-value & B (S. E.) & p-value \\
\hline Intercept & $\begin{array}{l}0.57 \\
(0.10)\end{array}$ & $\begin{array}{l}< \\
0.001 * * *\end{array}$ & $\begin{array}{l}0.16 \\
(0.13)\end{array}$ & 0.192 & $\begin{array}{l}-0.43 \\
(0.16)\end{array}$ & $0.008^{* *}$ \\
\hline \multicolumn{7}{|l|}{$\begin{array}{l}\text { Sector of employment (ref. is } \\
\text { academia) }\end{array}$} \\
\hline Non-academic R\&D & $\begin{array}{l}0.05 \\
(0.04)\end{array}$ & 0.159 & $\begin{array}{l}0.00 \\
(0.04)\end{array}$ & 0.940 & $\begin{array}{l}-0.18 \\
(0.06)\end{array}$ & $0.002 * *$ \\
\hline Non-R\&D & $\begin{array}{l}0.29 \\
(0.05)\end{array}$ & $\begin{array}{l}< \\
0.001 * * *\end{array}$ & $\begin{array}{l}0.10 \\
(0.06)\end{array}$ & 0.122 & $\begin{array}{l}-0.03 \\
(0.08)\end{array}$ & 0.723 \\
\hline \multicolumn{7}{|l|}{$\begin{array}{l}\text { Educational level required for } \\
\text { job (ref. is } P h D)\end{array}$} \\
\hline Bachelor or lower & $\begin{array}{l}0.39 \\
(0.10)\end{array}$ & $\begin{array}{l}< \\
0.001 * * *\end{array}$ & $\begin{array}{l}0.25 \\
(0.13)\end{array}$ & $0.049^{*}$ & $\begin{array}{l}0.10 \\
(0.16)\end{array}$ & 0.527 \\
\hline Master & $\begin{array}{l}0.17 \\
(0.04)\end{array}$ & $\begin{array}{l}< \\
0.001 * * *\end{array}$ & $\begin{array}{l}0.04 \\
(0.05)\end{array}$ & 0.412 & $\begin{array}{l}-0.18 \\
(0.07)\end{array}$ & $0.009^{* *}$ \\
\hline $\begin{array}{l}\text { Professional degree (e.g., M. } \\
\text { D.) }\end{array}$ & $\begin{array}{l}0.25 \\
(0.05)\end{array}$ & $\begin{array}{l}< \\
0.001^{* * * *}\end{array}$ & $\begin{array}{l}-0.06 \\
(0.07)\end{array}$ & 0.322 & $\begin{array}{l}0.14 \\
(0.08)\end{array}$ & 0.086 \\
\hline $\begin{array}{l}\text { Relatedness of current job to } \\
\mathrm{PhD} \text { topic }\end{array}$ & $\begin{array}{l}-0.08 \\
(0.02)\end{array}$ & $\begin{array}{l}< \\
0.001^{* * *}\end{array}$ & $\begin{array}{l}-0.05 \\
(0.02)\end{array}$ & $0.014^{*}$ & $\begin{array}{l}0.01 \\
(0.03)\end{array}$ & 0.727 \\
\hline $\begin{array}{l}\text { Field of PhD (ref. is } \\
\text { engineering and technology) }\end{array}$ & & & & & & \\
\hline Medical and health sciences & $\begin{array}{l}0.11 \\
(0.05)\end{array}$ & $0.041^{*}$ & $\begin{array}{l}0.04 \\
(0.07)\end{array}$ & 0.571 & $\begin{array}{l}0.19 \\
(0.08)\end{array}$ & $0.023^{*}$ \\
\hline Natural sciences & $\begin{array}{l}0.04 \\
(0.05)\end{array}$ & 0.400 & $\begin{array}{l}0.02 \\
(0.06)\end{array}$ & 0.748 & $\begin{array}{l}0.07 \\
(0.08)\end{array}$ & 0.365 \\
\hline Social sciences & $\begin{array}{l}0.04 \\
(0.06)\end{array}$ & 0.446 & $\begin{array}{l}0.03 \\
(0.07)\end{array}$ & 0.712 & $\begin{array}{l}0.14 \\
(0.09)\end{array}$ & 0.118 \\
\hline Humanities & $\begin{array}{l}-0.05 \\
(0.06)\end{array}$ & 0.388 & $\begin{array}{l}-0.10 \\
(0.08)\end{array}$ & 0.200 & $\begin{array}{l}-0.13 \\
(0.10)\end{array}$ & 0.181 \\
\hline Age at survey & $\begin{array}{l}-0.01 \\
(0.00)\end{array}$ & $\begin{array}{l}< \\
0.001 * * *\end{array}$ & $\begin{array}{l}-0.01 \\
(0.00)\end{array}$ & $0.003^{* *}$ & $\begin{array}{l}-0.01 \\
(0.00)\end{array}$ & $0.032^{*}$ \\
\hline Female & $\begin{array}{l}0.03 \\
(0.03)\end{array}$ & 0.355 & $\begin{array}{l}0.01 \\
(0.04)\end{array}$ & 0.842 & $\begin{array}{l}0.05 \\
(0.05)\end{array}$ & 0.313 \\
\hline
\end{tabular}

${ }^{*},{ }^{* *}$, and ${ }^{* * *}$ denote statistically significant difference of the independent variable at the 5,1 , and $0.1 \%$ levels, respectively.

\section{Acknowledgements}

We would like to thank Rosalie Belder, Hans Sonneveld and Cornelis van Bochove for their feedback when constructing the questionnaire. Janna de Wit and Ruben Bos are thanked for their exploration of the data. Finally, we would like to thank Cornelis van Bochove for his comments on the manuscript draft. 


\section{Bio Authors}

Julia Heuritsch studied Astronomy at the University of Vienna, the Australian National University and the University of Leiden. By the time she finished her Master in the summer of 2015, she had become unhappy with the "publish or perish system" prevailing in science. She found that the way in which our funding, publication and career systems work does not encourage an efficient knowledge-production process with highquality outputs. This is the reason why she moved to Science Policy - in other words, research about research. She worked at the Centre for Science and Technology Studies in Leiden for 2 years, before starting her new appointment as a $\mathrm{PhD}$ candidate at Humboldt University in Berlin in February 2018.

Cathelijn Waaijer has been a PhD candidate at the Centre for Science and Technology Studies in Leiden, the Netherlands from 2012 until 2016. She successfully defended her PhD thesis on career insecurity of early career researchers in November 2016. She has since had a brief stint as a postdoctoral researcher at the Center for Innovation in Medical Education at Leiden University Medical Center, before taking up her present position as a policy advisor and institutional researcher at Leiden University.

Inge van der Weijden is a senior researcher, lecturer and $\mathrm{PhD}$ coordinator at the Centre for Science and Technology Studies, Leiden University. Her main research interests are situated in the area of career paths of academics, academic leadership and management and research evaluation. Inge is president of The Netherlands Centre of Expertise for Doctoral Education. Between 2006 and 2011 Inge worked in research policy for the Rathenau Institute (The Netherlands) and was involved in various studies concerning the organization and development of science systems. Inge holds a PhD in organizational sciences from the VU Amsterdam (2007), with a background in policy and management in medical biology (MSc 1999). 


\section{Declaration of interest statement: none}

\section{References}

Anonymous author. 2014. "There is Life after Academia." Nature 513 (7516), 5-5. doi: $10.1038 / 513005 a$.

Auriol, L., M. Misu, and R.A. Freeman.2013. Careers of Doctorate Holders: Analysis of Labour Market and Mobility Indicators. Paris: OECD. doi: 10.1787/18151965.

Bartelse, J., H. Oost, and H. Sonneveld. 2007. "Doctoral Education in the Netherlands." In The Doctorate Worldwide, edited by S. Powell and H. Green, 64-76. Maidenhead: Open University Press.

de Jonge, J. 2018. Factsheet Academic careers of researchers. The Hague: Rathenau Instituut. .

de Goede, M., R. Belder, R., and J. de Jonge. 2014. Promoveren in Nederland: Motivatie en loopbaanverwachtingen van promovendi. The Hague: Rathenau Instituut.

De Grande, H., K. De Boyser, K. Vandevelde, and R. Van Rossem. 2014. "From Academia to Industry: Are Doctorate Holders Ready?” Journal of the Knowledge Economy 5 (3), 538-561. doi: 10.1007/s13132-014-0192-9.

Diamond, A., C. Ball, T. Vorley, T. Hughes, R. Moreton, P. Howe, and T. Nathwani. 2014. The Impact of Doctoral Careers. Leicester: CFE Research.

Durette, B., M. Fournier, and M. Lafon. 2016. "The Core Competencies of PhDs.” Studies in Higher Education 41 (8), 1355-1370. doi: 10.1080/03075079.2014.968540.

Ehrlinger, J., and D. Dunning, D. 2003. "How Chronic Self-Views Influence (and Potentially Mislead) Estimates of Performance.” Journal of Personality and Social Psychology 84 (1), 517. doi: $10.1037 / \mathrm{a} 0017452$. 
Enders, J. 2002. "Serving Many Masters: The PhD on the Labour Market, the Everlasting Need of Inequality, and the Premature Death of Humboldt." Higher Education 44 (3-4), $493-$ 517. doi: 10.1023/A:1019850524330.

Fitzenberger, B., and U. Schulze. 2014. "Up or Out: Research Incentives and Career Prospects of Postdocs in Germany." German Economic Review 15 (2), 287-328. doi: 10.1111/geer.12010.

Fugate, M., A. J. Kinicki, and B. E. Ashforth. 2004. "Employability: A psycho-social construct, its dimensions, and applications." Journal of Vocational Behavior 65 (1), 1438. doi: 10.1016/j.jvb.2003.10.005.

Government of the Netherlands. 2015. Ontwerpbesluit experiment promotieonderwijs (B10335.K-1). The Hague: Government of the Netherlands.

Haapakorpi, A. 2017. "Doctorate Holders Outside the Academy in Finland: Academic Engagement and Industry-Specific Competence." Journal of Education and Work 30 (1), 5368. doi: 10.1080/13639080.2015.1119257.

Hayter, C.S., and M.A. Parker. 2019. "Factors that influence the transition of university postdocs to non-academic scientific careers: An exploratory study." Research Policy 48, 556570. doi: 10.1016/j.respol.2018.09.009

Kehm, B. M. 2006. "Doctoral Education in Europe and North America: A Comparative Analysis." In The formative years of scholars, edited by U. Teichler, 67-78. London: Portland Press.

Kyvik, S., and T. B. Olsen. 2012. "The Relevance of Doctoral Training in Different Labour 
Markets." Journal of Education and Work 25 (2), 205-224. doi:

$10.1080 / 13639080.2010 .538376$.

Lorenzo-Seva, U., and P. J. Ferrando. 2006. "FACTOR: A Computer Program to Fit the

Exploratory Factor Analysis Model.” Behavior Research Methods 38 (1), 88-91. doi:

10.3758/BF03192753.

Maas, B., M. Korvorst, F. van der Mooren, and R. Meijers. 2014. Careers of Doctorate

Holders in the Netherlands, 2014. The Hague: Statistics Netherlands.

McQuaid, R. W., and C. Lindsay. 200). "The Concept of Employability.” Urban Studies

42 (2), 197-219. doi: 10.1080/0042098042000316100.

OECD. 2002. Frascati Manual: Proposed Standard Practice for Surveys on Research and

Experimental Development. Paris: OECD. doi: 10.1787/19900414.

Onderwijs in Cijfers. 2019. https://www.onderwijsincijfers.nl/kengetallen/wo/studenten-

wo/aantallen-ontwikkeling-aantal-gepromoveerden

Platow, M. J. 2012. "PhD experience and subsequent outcomes: a look at self-perceptions of acquired graduate attributes and supervisor support." Studies in Higher Education

37 (1), 103-118. doi: 10.1080/03075079.2010.501104

Puljak, L., and W. D. Sharif. 2009. "Postdocs' perceptions of work environment and career prospects at a US academic institution." Research Evaluation 18 (5), 411-415. doi: $10.3152 / 095820209 X 483064$.

Rip, A. 2004. "Strategic Research, Post-modern Universities and Research Training." Higher Education Policy 17 (2), 153-166. doi: 10.1057/palgrave.hep.8300048.

Sauermann, H., and M. Roach. 2012. "Science PhD Career Preferences: Levels, Changes, and Advisor Encouragement." PLoS ONE, 7(5). doi: 10.1371/journal.pone.0036307. 
Sin, C., and G. Neave. 2016. "Employability Deconstructed: Perceptions of Bologna

Stakeholders." Studies in Higher Education 41(8), 1447-1462. doi:

$10.1080 / 03075079.2014 .977859$

Skovgaard Pedersen, H. 2016. “Are PhDs Winners or Losers? Wage Premiums for Doctoral Degrees in Private Sector Employment.” Higher Education 71 (2): 269-287. doi: 10.1007/s10734-015-9901-y.

Sonneveld, H. 1997. Promotoren, Promovendi en de Academische Selectie: De Collectivisering van het Nederlandse Promotiestelsel. Amsterdam: Amsterdam University Press.

Sonneveld, H., M. Yerkes, M., and R. van de Schoot. 2010. Ph.D. Trajectories and Labour Market Mobility: A Survey of Recent Doctoral Recipients at Four Universities in the Netherlands. Utrecht: Netherlands Centre for Graduate and Research Schools, Utrecht. https://ssrn.com/abstract=1919048.

Stassen, L., K. Levecque, and F. Anseel. 2016. PhDs in Transition: What Is the Value of a PhD Outside Academia? Gent: UGent.

Stemwedel, J. D. 2013. Careers (Not Just Jobs) for Ph.D.s outside the Academy. New York: Scientific American. https://blogs.scientificamerican.com/doing-good-science/careers-notjust-jobs-for-phds-outside-the-academy/.

te Kaat, A., and K. Vandevelde. "Competencies of Doctorate Holders." In Careers of Doctorate Holders Survey, edited by K. Boosten and K. Vandevelde, 32-35. Brussels: ECOOM, 2010.

Traag, T., and H.-J. Dirven. 2008. "Arbeidsmarktpositie van Gepromoveerden.” Sociaaleconomische trends 8(4), 51-57. 
https://www.vsnu.nl/files/documenten/Domeinen/Personeel/Feiten\%20en\%20Cijfers\%20jong e\%20wetenschappers/Arbeidsmarktpositie\%20van\%20gepromoveerden.pdf

van der Steeg, M., K. van der Wiel, and B. Wouterse. 2014. Individual Returns to a PhD Education in the Netherlands: Income Differences between Masters and PhDs. The Hague: Centraal Planbureau. https://www.cpb.nl/en/publication/individual-returns-to-a-phdeducation-in-the-netherlands-income-differences-between-masters-and-phds .

van der Weijden, I. C. M., E. J. de Gelder, C. Teelken, and M. Thunnissen. 2017. Which Grass Is Greener? Personal Stories from PhDs about Their Careers within and outside of Academia. Leiden: Centre for Science and Technology Studies. http://hdl.handle.net/1887/59447.

Waaijer, C. J. F., R. Belder, H. Sonneveld, C. A. van Bochove, and I. C. M. van der Weijden. 2015. Survey on the Labour Market Position of PhD Graduates: Development of a Novel Questionnaire. Leiden: Centre for Science and Technology Studies. http://hdl.handle.net/1887/32604.

Waaijer, C. J. F., R. Belder, H. Sonneveld, C. A. van Bochove, and I. C. M. van der Weijden. 2017. Temporary Contracts: Effect on Job Satisfaction and Personal Lives of Recent PhD Graduates. Higher Education 74 (2), 321-339. doi: 10.1007/s10734-016-0050-8.

Waaijer, C. J. F., A. Heyer, and S. Kuli. 2016. Effects of Appointment Types on the Availability of Research Infrastructure, Work Pressure, Stress, and Career Attitudes of PhD Candidates of a Dutch University. Research Evaluation 25(4), 349-357. doi: 10.1093/reseval/rvw008.

Yorke, M. 2006. Employability in Higher Education: What It Is - What It Is Not. York: The Higher Education Academy. 
